\title{
Capstone Engineering Design Projects For Community Colleges
}

Kenneth A. Walz, Madison Area Technical College, USA

Jon R. Christian, Madison Area Technical College, USA

\begin{abstract}
Capstone engineering design courses have been a feature at research universities and four-year schools for many years. Although such classes are less common at two-year colleges, the experience is equally beneficial for this population of students. With this in mind, Madison College introduced a project-based Engineering Design course in 2007. This paper explores Madison College's experience over the past decade offering this class. Unique challenges and opportunities for engineering design courses at two-year colleges are discussed. Our findings include several recommended practices to benefit colleges and universities at any level that are creating new engineering design courses.
\end{abstract}

Keywords: Capstone; Engineering; Design; Two-Year College; Community College; Technical College

\section{INTRODUCTION}

\section{Engineering Education at Community Colleges}

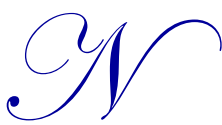

early 8 million students attend two-year community and/or technical colleges each year, accounting for $45 \%$ of all undergraduate students (AACC, 2016). As of 2016, there were 274 ABET accredited engineering associate degree programs offered by ninety-four different two-year colleges in the United States (ABET, 2016). The Department of Labor has identified several engineering technology careers requiring two-year associate degrees that offer median pay rates of $\$ 35 \mathrm{~K}-\$ 75 \mathrm{~K}$ per year, and could account for as many as 75,000 new positions by the year 2024 (US DOL, 2016).

For many engineering students, the two-year college is an on-ramp that serves as the starting point for their higher education. A large number of two-year colleges offer pre-engineering associate degrees that articulate with engineering programs at partnering four-year universities. A National Science Foundation Report found that $72 \%$ of science and engineering bachelor's degree holders over age 50, and 62\% of female students with children had attended a community college (Tspogas, 2004). A more recent National Science Foundation study found that $41 \%$ of all STEM master's degree students and $26 \%$ of engineering master's degree students had attended a community college. Among doctorate recipients, 12\% had earned college credit from a two-year college at some point on their academic path (NSF, 2010). This included 16\% of Black, 21\% of Hispanic and 25\% of Native American Ph.D. degree recipients.

Given these statistics, it is clear that two-year community and technical colleges have a significant role to play in educating the engineers of the future. In this paper, we advocate that engineering design projects should be incorporated into the curriculum for engineering programs at two-year schools. We describe our experience at Madison College, and present some of the challenges and opportunities that we have encountered. Our findings include several recommended practices to benefit colleges and universities at any level that are creating new engineering design courses.

\section{THE ENGINEERING DESIGN EXPERIENCE AT MADISON COLLEGE}

Madison College's Engineering Design class was created in 2007 in order to support a new 2+2 transfer agreement with the University of Wisconsin-Madison. The course is an interdisciplinary class that includes students from all 
engineering programs. Some of the students are pursuing specific engineering technology associate degrees at Madison College, while others are enrolled in pre-engineering transfer pathways. The majority of students enrolled in the design class are civil, electrical and mechanical engineers, but we have also had students pursuing degrees in aerospace, agricultural, biomedical, chemical, environmental, industrial, materials science and nuclear engineering. The course is offered in the spring semester, and for most students this is the last engineering class that they take before graduating from the college and entering the workforce or transferring to the university to complete a bachelor's degree. Class sections have ranged in size from 10 to 15 students, and in recent years, multiple sections have been run in parallel to meet increased student demand. In the past decade, roughly 250 students have completed the Engineering Design course.

\section{Engineering Design vs. Scientific Method}

For the vast majority of students taking this course, this is their first exposure to engineering design. Typical engineering programs emphasize core math and science coursework in their first two years of study. Although there are similarities between the scientific method and the engineering design process, they are distinctly different from one another (see Table 1). For many students taking this course, it may be their only exposure to engineering design while at the two-year college, and hence we view this class as an especially valuable experience for workforce preparation.

Table 1. Comparison between Scientific Method and Engineering Design

\begin{tabular}{l|l}
\hline \multicolumn{1}{c}{ Scientific Method } & \multicolumn{1}{c}{ Engineering Design } \\
\hline State a question and/or hypothesis & Identify client's problem and/or needs \\
\hline Gather background information & Gather background information \\
\hline Formulate a hypothesis & Establish design constraints and criteria \\
\hline Identify variables and design experiment & Create preliminary designs \\
\hline Conduct experiment and test hypothesis & Build and test prototype(s) \\
\hline Analyze results and draw conclusions & Assess and redesign - repeat as necessary \\
\hline Share results with others & Share results with client \\
\hline
\end{tabular}

\section{Real World Projects \& Clients}

The Engineering Design class at Madison College employs project-based learning that is focused on serving the needs of a client. In this way, the class places students in the role of practicing engineering teams, modeling the processes and interactions used in the real world. This is a powerful example of what educators sometimes refer to as an "authentic" learning experience (Rule, 2006; Lombardi, 2007). Clients for student projects have included other schools, programs, or departments from within the academic community, local government and public entities, non-profit organizations and start-up companies founded by recent alumni. Examples of engineering design projects and clients are included in Table 2.

It is important to note the significance of students working for an external client. This is a highly motivating factor that drives student performance. It is intrinsically rewarding for students to realize that they can apply their knowledge and skills to benefit the local community on projects such as cleaning up local beaches, designing ultralow emission wood stoves, or creating energy efficient low-income housing for local residents. Likewise, projects that benefit fellow students and that support student entrepreneurs seeking to start local businesses are very appealing. It is not unusual at the conclusion of the design project for student evaluations to include comments reflecting that they had "worked harder" for this class, that they "learned more" from this experience than any other, or that they "cared more" about their design project in comparison to their previous academic studies. In many cases, students were so highly engaged in their design projects that they continued their relationships with the client after the official class had ended; in several instances, students secured internships or other paid employment with the client. 
Table 2. Engineering clients and design projects completed at Madison College

\begin{tabular}{l|l|c}
\hline \multicolumn{1}{|c|}{ Project } & \multicolumn{1}{c}{ Client } & \multicolumn{1}{c}{ Type } \\
\hline Biodiesel reactor and biofuel blending unit & Madison College Diesel Technology Program & A \\
\hline Handicap accessible playground for disabled children & Hackett-Hemwall Foundation & A \\
\hline Wind turbine for developing world applications & Madison College Renewable Energy Program \\
\hline Solar photovoltaic panel test apparatus & UW Madison and Solar Kleen Tech & A, D \\
\hline Low-carbon footprint food cart for a start-up vendor & Igo Vego - Organic Foods & D \\
\hline $\begin{array}{l}\text { Turf grass cultivation system for nutrient removal at a } \\
\text { community biogas digester }\end{array}$ & $\begin{array}{l}\text { Dane County Community Digester and Great Lakes } \\
\text { Ag Energy }\end{array}$ & B, D \\
\hline Net-zero energy home & City of Madison Community Development Association & B \\
\hline Algae collection device for cleaning beaches on inland lakes & $\begin{array}{l}\text { City of Madison Parks Department and Clean Lakes } \\
\text { Alliance }\end{array}$ & B, C \\
\hline Grain handling unit for start-up microbrewery & Karben 4 & D \\
\hline Digital Music imaging and archiving system & Murfie & D \\
\hline Improved tools for street gutter leaf removal & $\begin{array}{l}\text { City of Madison Streets Division and Clean Lakes } \\
\text { Alliance }\end{array}$ & B, C \\
\hline Ultra-low emission wood biomass stove & USDA Forest Products Lab \\
\hline Incubation vessel for chicken egg stem cell research & University of Wisconsin Institute for Discovery \\
\hline A = academic, B $=$ public entity, C $=$ non-profit organization, D = private start-up company & B \\
\hline
\end{tabular}

$\mathrm{A}=$ academic, $\mathrm{B}=$ public entity, $\mathrm{C}=$ non-profit organization, $\mathrm{D}=$ private start-up company

One of the strongest rationales for offering engineering design project-based learning is that there are several key engineering experiences that are not easily taught using other methods (See Table 3). It is important to note that these are many of the same skills that are in high demand by employers (Jackson, 2011; Murray, 2013;). Because these skills are not specific to an individual academic discipline and are difficult to assess quantitatively, they often slip through the cracks in academic programs. This can lead to the so called "skills gap" that is lamented by many employers (Weiner, 2014; Hutchins, 2015). We have observed that these experiences are also what make the engineering design class so valuable to students. Many of our students have commented on end of semester evaluations that the course is "unlike anything else", or that it was the "best preparation" for their future career. In particular, open-ended problem solving is something that is rarely taught in undergraduate education. In many cases, students become so involved with their engineering design projects that they seek out extra time for fabrication shop access, working on nights or weekends. One group of students affectionately came to refer to engineering design as "The Class that Never Ends". While this might make the experience sound like a daunting workload, it is important for students to realize that this is exactly how business and industry function in the real world. Engineering design does not end with the fabrication of the initial product. Rather, the process of evaluating, re-designing, and improving on that product is a never-ending continuous cycle.

Table 3. Key engineering experiences not easily taught using other methods

\begin{tabular}{l}
\hline Client Relationships \\
Working in Interdisciplinary Teams \\
\hline Time and Project Management \\
\hline Budget and Accounting \\
\hline External Relations and Communications \\
\hline Personal Responsibility and Accountability \\
\hline Conflict Resolution and Decision Making \\
\hline Familiarization with Business and Industry \\
\hline Familiarization with Manufacturing \\
\hline Technical Writing \\
\hline Perseverance when Faced with a Challenge \\
\hline Open-Ended Problem Solving \\
\hline
\end{tabular}




\section{Hands-on Fabrication of Prototypes}

Another key aspect of our Engineering Design course is hands-on fabrication of scale models and prototypes. This provides familiarization with tools, machines, and manufacturing methods for students that lack this background. In generations past, many students might have gained these experiences through growing up on a farm or through high school vocational and technical education courses. Many engineers of the authors' age grew up repairing tractors or combines, operating milking equipment, and/or raising barns. Others can recall high school experiences in drafting, small engine and auto repairs, woodworking, and metalwork/foundry. Relevant life experiences such as these have become less common for younger college engineering students. Today, while the majority of engineering students on our campuses have taken advanced placement calculus, physics and chemistry, many of them lack experience working with their hands or even basic knowledge of fabrication processes (Stauth, 2002; Malicky, et al. 2012; Atwater, 2014). By teaching not only design, but also fabrication, we have attempted to help bridge this gap for our students.

Fabrication of prototypes also allows for several other benefits relevant to the engineering profession. It is not uncommon for students to find that a design that "looked great on paper" fails to live up to its initial promise. In some cases, the fabrication process itself exposes design weaknesses or oversights that the engineers did not initially foresee (e.g. blind welds, missing fasteners, or unstable structures). Additionally, once prototypes have been fabricated, they universally fail in some aspect during product testing. In this way, students are able to assess their designs, evaluate design strengths and weaknesses, and then problem solve and re-design to address shortcomings. Thus, students come to appreciate the iterative nature of engineering design, which is standard practice in business and industry.

Figure 1. Computer aided drawings and 3d-printed prototypes for several egg incubation vessels that were designed, fabricated and tested by Madison College engineering students for stem cell research
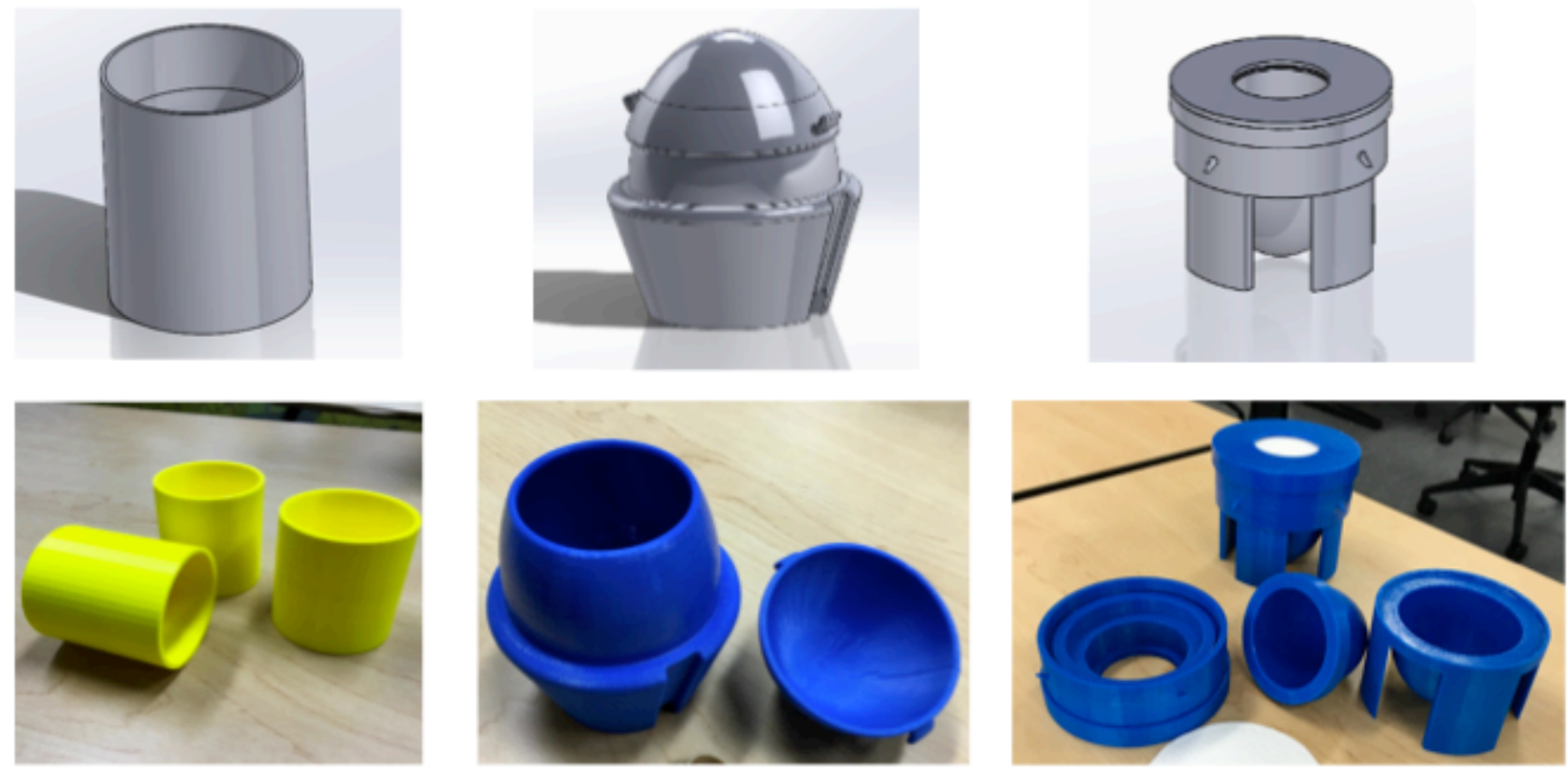

\section{Unique Project Opportunities at Two-Year Colleges}

Teaching at a two-year college offers some unique opportunities for implementing engineering design projects. The average age of a community college student is 28 and most of these students work at least 30 hours per week (AACC , 2016). As a result, community college students generally have more relevant prior work experience than those at four-year universities. This often allows for more ambitious project undertakings. For example, when 
constructing playground equipment for children with special needs, this team was fortunate to have a team member who had previously worked in residential home construction, and others who had worked as welders. These skills proved very helpful when building the staircase and slide structures, and when welding swing sets and soccer goals. Furthermore, since many two-year college students are adult learners with families of their own, they bring another level of understanding to the problem at hand. In the case of the playground project, some of our students brought their own children to school to serve as focus-group subjects to field-test the playground equipment that the class designed and fabricated.

When teaching at a two-year college, there is also the opportunity to take advantage of the various technical programs and resources that would not typically be found at a four-year school. Community and technical colleges usually have robust fabrication teaching facilities, offering machines and instruments that may not be readily available at universities. For example, students working on the biomass stove project at Madison College had access to the school's welding labs, and students fabricating a small $1 \mathrm{~kW}$ wind turbine were able to use a CNC mill to shape the airfoil on the wooden blades and a plasma cutter to cut the hub and tail pieces. Students working on the biodiesel reactor and biofuel blending apparatus were able to collaborate with faculty and students in the diesel technology program, who ultimately used the fuel that was produced to power various trucks, tractors and other machinery operated by the mechanics.

Figure 2. One of the authors assists a group students welding a crossbeam for a handicap accessible swing set

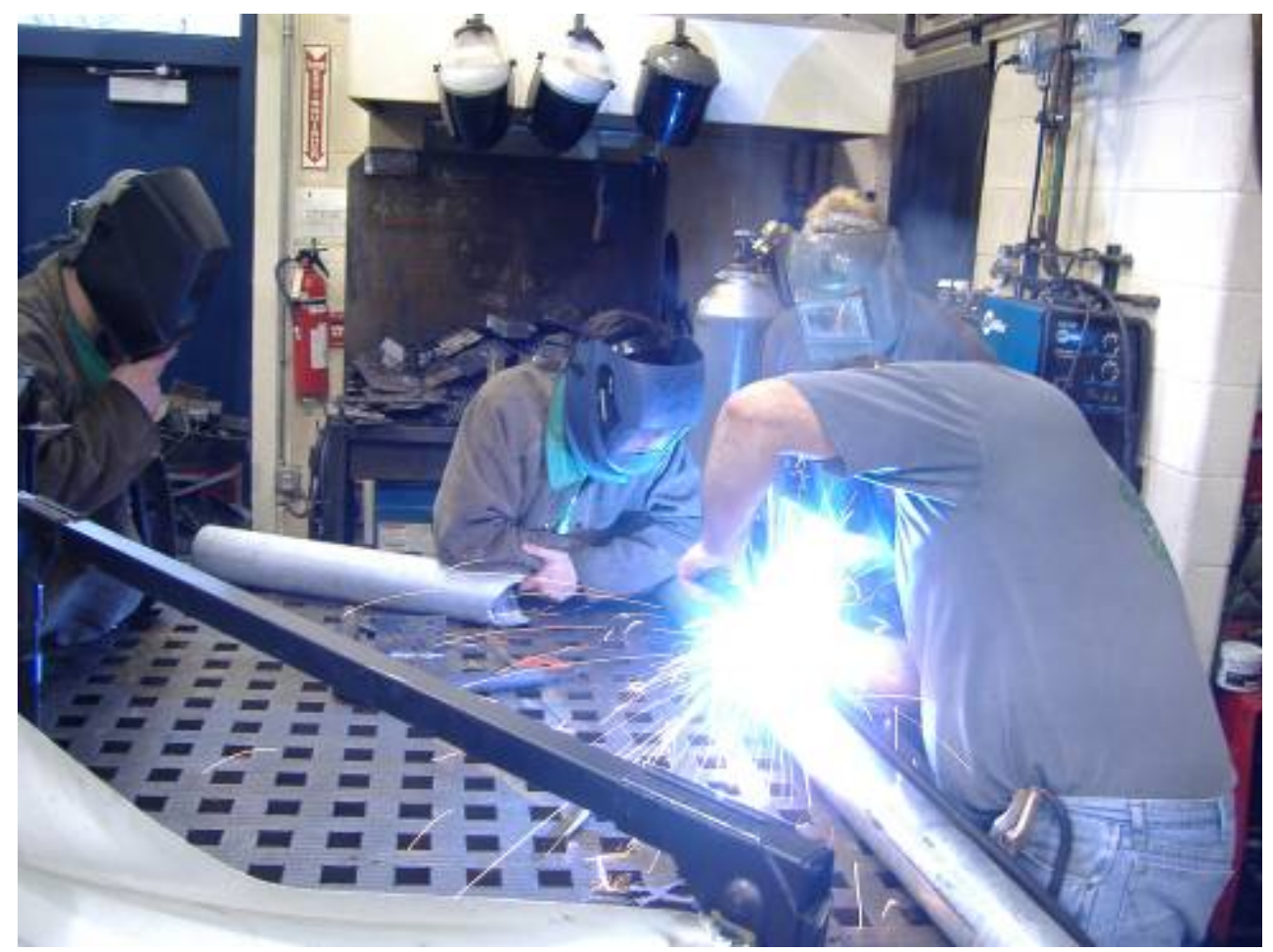

Like many other two-year schools, Madison College has a close relationship with our four-year partners at the University of Wisconsin-Madison. This has provided many additonal opportunities for collaboration. For example, a recent engineering design team worked for a client from the UW Institutes for Discovery. The UW lab is researching the early embryonic development of chicken eggs with the hope of developing new stem cell techniques to develop neurological and organ replacement treatments. The lab was confronted by a problem with early mortality of chick embryos, which was ultimately resolved when the community college team designed, fabricated and tested a series of incubation vessels that improved the viability of the embryos by a factor of more than $10 \mathrm{X}$. Another partnership that has evolved over the years involved the engagement of university graduate students with 
community college engineering design projects. For example, Madison College students designed a solar photovoltaic test apparatus that was subsequently used by several graduate students at the university to measure the performance of self-cleaning glass coatings to improve power generation. This work ultimately led to the formation of a small start-up company spun out of the university. Several other university graduate students have been involved with engineering design projects in various ways, and some of these have led to peer-reviewed journal publications for the student authors (Hoffman et al. 2011; Walz et al, 2014; Gillian-Daniel and Walz, 2016). In a couple of cases, involvement with the engineering design projects was a motivating factor that pushed Madison College students to continue their education beyond their B.S. degree. Two of these students are now enrolled in graduate programs.

Figure 3. One of the authors works with a UW graduate student on a photovoltaic panel test apparatus, designed and fabricated by undergraduate engineering students at Madison College.

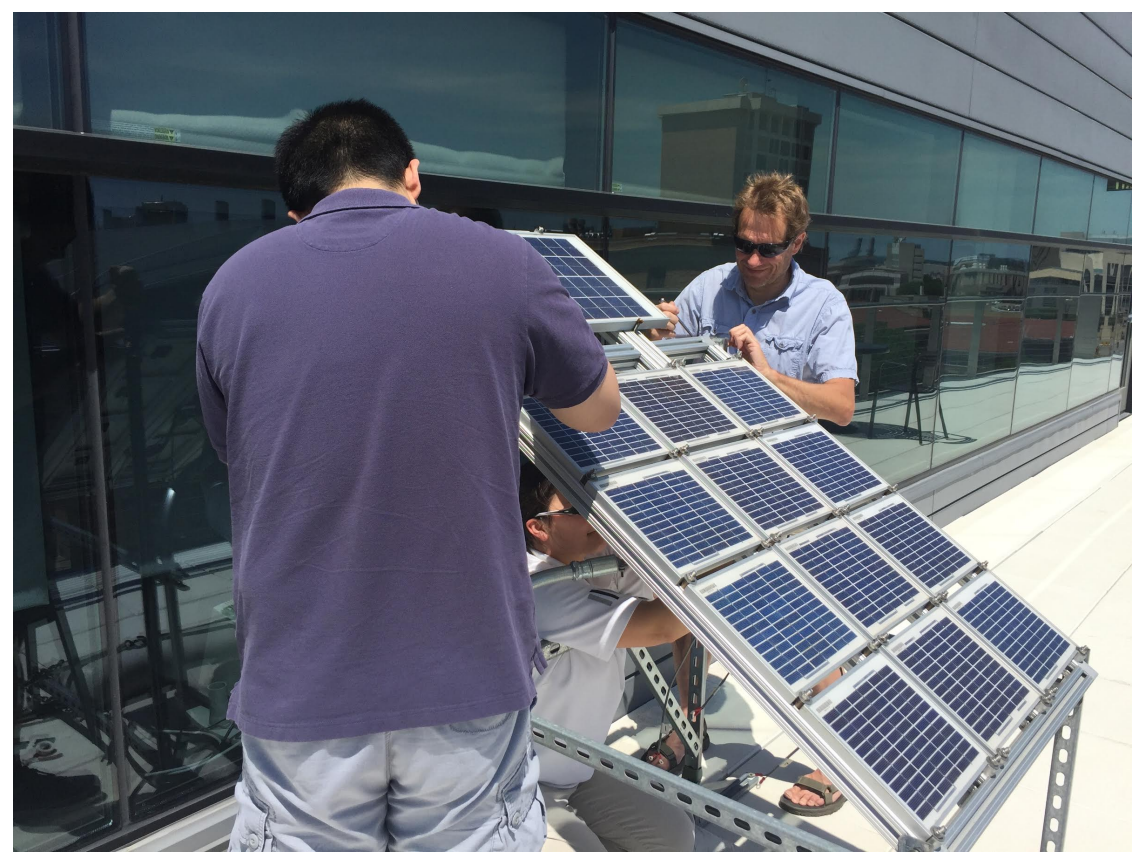

\section{CHALLENGES AND RECOMMENDED PRACTICES}

In implementing the engineering design class at Madison College, we have encountered several challenges over the past ten years. Here we share the most significant of these, along with recommended practices so that others can learn from our experience.

\section{Project and Client Selection}

Selection of clients is one of the most time-consuming aspects of implementing engineering design capstone projects. We typically begin conversations to screen potential clients a full year in advance. Although many people will express interest in working with students, not every possible opportunity will be suitable. Meeting with potential clients, discussing their needs and determining feasibility can be daunting tasks and take up a large part of a faculty member's time.

\section{Recommended Practices:}

We have developed a checklist of criteria that we now use to screen potential clients (See Table 4). Having this list available, and sharing this list with prospective clients, often helps to make quick decisions about the viability of a 
given project. When considering this list, the first two items are the most important. Because these are student projects, it is not possible to guarantee a successful solution to the client's needs. Furthermore, if the client has a rigid deadline, it usually is not possible to guarantee completion of the project on time. These factors are often deal breakers for many prospective clients. Start-up companies in particular are working on small budgets and tight time constraints, and cannot wager the success or failure of their business on a student design project. For this reason, it is very important to share up front with the client the limitations of what can be done with student projects.

Table 4. Criteria for screening potential engineering design project clients

\begin{tabular}{l} 
Client must be flexible on ultimate success or failure of the project \\
Must be achievable in a 4 month timeframe \\
Must be within affordable range \\
Client must be available to meet with students frequently \\
Project must be within the technical capabilities of the students \\
Instructors must feel reasonably confident that they can mentor a team to deliver a workable solution. \\
\hline
\end{tabular}

\section{Team Dynamics}

As engineering teachers are surely aware, most of our students have somewhat limited experience working in teams. Furthermore, many of them initially resist the idea that their success - and their grade - will be determined in part on their ability to work with others.

\section{Recommended Practices:}

To facilitate team dynamics, we have adopted several approaches. To begin, instructors must acknowledge the need to teach team skills. Our work with this starts on day one, as students engage in a team tower building exercise using paper and scotch tape. This continues on the second day of class, with teams engaged in a design scavenger hunt. Additional team exercises are scheduled throughout the semester. We also actively teach team dynamics. We discuss effective team management techniques, emphasizing the need to make sure that all voices are heard and all contribute to the engineering design process. We also teach decision-making and conflict resolution strategies. Lastly, we engage students in evaluating their team function, tasking them throughout the semester with several peer and self-assessments.

\section{Instructor Expertise}

When initially creating this course, Madison College struggled to find faculty members willing to teach it. Many engineering instructors do not have the necessary experience or technical skills to supervise complex fabrication tasks. Likewise, many of the best welding, construction or electrical instructors at two-year colleges lack formal training in engineering.

\section{Recommended Practices:}

The solution to this challenge was team teaching. At Madison College we have offered this class with teams ranging from 2 to 4 instructors working collaboratively. The teams always include at least one traditionally educated engineer and at least one master fabricator. We found that team teaching has multiple added benefits. For many of our projects, no single individual instructor felt that they possessed the expertise necessary to implement these projects, but through a combined effort we were able to draw on our collective experience and advise students to successful outcomes. Team teaching is also an excellent way to model team dynamics. Students are able to watch us work as a team and share ideas. In cases where we might have diverging opinions, students observe the instructors utilizing model decision-making strategies to reconcile conflicting points of view and to arrive at satisfactory conclusions. 


\section{Irregular Work Schedules}

Unlike ordinary academic classes, engineering design projects may often require irregular work schedules for faculty. This may also include off-site work at client workplaces or other designated field locations. Furthermore, in our experience, students almost always find themselves in a time crunch towards the end of their design projects, and frequently are scrambling to find additional fabrication shop time. This may require faculty to make themselves and the facilities available during evening or weekend work hours that are outside the boundaries of the normal teaching workload.

\section{Recommended Practices:}

This is another area where team teaching offers huge benefits. Having multiple instructors allows for splitting teams into small groups where one faculty member can accompany a smaller number of students to a field site, while the other faculty member remains on campus with the larger class as a whole. Multiple instructors also allows for sharing the workload for irregular hours, so that no single individual has to shoulder the entire burden. In recent years, we have also been fortunate to hire some of our engineering alumni to return to the college and work as instructional assistants. This adds yet another member to the teaching team, which makes it possible to schedule additional open shop time for students. As recent engineering graduates, these individuals are also excellent role models for their younger peers.

\section{Budget and Purchasing}

Having access to adequate financial resources is always a challenge; ultimately, the size of the budget will limit the types of engineering design projects that can be done. Additionally, engineering design classes present challenges for conventional purchasing processes commonly used at college campuses. For many college courses (e.g. math, English and humanities) the supply budgets are minimal. And for those courses with substantial supply needs, the budgets are at least predictable from one year to the next (e.g. biology, chemistry, construction and welding). However, this is not the case with engineering design projects. Faculty do not know what they will need to buy at the start of semester, and they will not have that information until the student designs are finalized and approved by their clients. This makes it very hard to plan ahead to set up standing purchase orders, to identify college approved vendors, and to comply with various college purchasing guidelines. Furthermore, since the students are working on a rather tight design and fabrication deadline, attention must be paid to shipping and handling constraints. Supplies and other items that are out of stock, backordered, imported, or that have long shipping lead times can cause serious disruptions to engineering design project management schedules.

\section{Recommended Practices:}

Although specific purchasing needs are not known for any individual design project, we have found that most projects require a minimum budget of about $\$ 300$ to achieve meaningful results for the clients. At Madison College, we have implemented a course materials fee that is assessed to students to cover part of this cost. Projects that exceed this amount can be further supplemented with financial contributions from the client. It is important for instructors to discuss budget limits with the client when scoping the feasibility of the project. Students must also develop accurate cost estimates for their designs, and obtain client approval of their designs before spending money on fabrication. For some projects that benefit the community or non-profit organizations, students have been successful in soliciting charitable donations on behalf of their clients, in order to offset cost.

Because every student design project is unique, requiring novel supplies, parts, and equipment, we have found that it is necessary for instructors to be issued a corporate purchasing credit card in the college's name. This allows instructors to place orders and obtain materials on an as needed basis, without the delays that would otherwise occur going through the college requisition process. Alternatively, students may ask the client to purchase materials themselves, and have them delivered directly to the college. On many occasions, it is beneficial to work with local vendors. Often times a simple phone call can verify inventory, and if students are willing to pick up items, they can get same day service. We cannot count the number of times that we had to send "runners" to the local hardware store to replace a broken tool, to buy extra fasteners, or to get a spare $2 \times 4$ or length of threaded rod after a piece was 
mistakenly cut to the incorrect length. The ability to make fast "buy on the fly" purchases has saved many engineering design student projects that otherwise might not have been completed before the inflexible end of semester deadline.

\section{Variable Curriculum}

In any college course, students arrive with different backgrounds and skills. What is unique about engineering design projects is that not every student leaves with the same outcomes. This is somewhat unusual for two-year college programs, where courses typically are crafted with tightly defined learning objectives. Because engineering projects vary from year to year, the technical content will vary accordingly. It can be challenging for college administrators to understand exactly what is taught in an engineering design class and how this class fits into the larger academic curriculum. Likewise, because the projects are team efforts, individual students take responsibility for different aspects of the project, and thus may have very different individual experiences in the course.

\section{Recommended Practices:}

When documenting learning objectives for engineering design classes, we suggest that faculty should emphasize that they are teaching the engineering design process. In any given year the clients will have different needs, the design teams may include students from different engineering disciplines, the eventual designs will solve radically different problems, and they may use various different materials and fabrication techniques. However, the engineering design process is applicable for all engineering disciplines and can be used to address any engineering challenge.

By emphasizing the design process, learning objectives are less about particular technical knowledge, and more about the key professional and interpersonal skills that employers ask for; namely, communication skills, teamwork, time management, shared decision making and conflict resolution. In addition, it is useful to emphasize specific technical skills that are used almost universally in any engineering design project. Examples include reading blueprints, creating a scale drawing, developing a Gantt chart, technical writing, presentation skills and use of computer software applications (e.g. spreadsheets and computer aided drawing tools).

\section{Scaling up to Meet Student Demand}

By far the biggest challenge with engineering design courses is scaling up to meet student demand. When this course began at Madison College in 2007, a total of ten students completed the class with the two authors serving as instructors. In spring of 2016, sixty students enrolled in the course and the instructional team had been expanded to include four of us. In addition to the strain on faculty resources, scaling up also presents challenges for facilities. Typical engineering design projects will need access to classroom space, as well as computer lab space and fabrication shop space. Furthermore, the fabrication needs are somewhat unpredictable from one year to the next. While some projects require access to a wood shop, others might need access to welding booths, and yet others might require an outdoor construction yard. This puts strain on administrators and support staff who must deal with scheduling a class that might require access to three different rooms, while also juggling multiple faculty schedules and teaching workloads.

\section{Recommended Practices:}

It is important that faculty teaching engineering design project-based classes take an active role in helping to mentor additional instructors to scale up and serve more students. At Madison College, we have done this by recruiting other engineering instructors to team-teach with us, to "break them in" to the engineering design class. Joining a veteran instructional team provides an easier learning curve for teachers who are inexperienced with project-based coursework. We have also tried to cultivate new connections across campus by engaging instructors from other departments and programs, such as industrial maintenance and mathematics. In this way, we build faculty relationships, which eases access to shop facilities, tools, equipment and other resources.

Lastly, we cannot overstate the fact that faculty need to advocate for and demonstrate the relevance of engineering design projects. Because this course creates extra demands - and extra work - for teachers, administrators and 
support staff, it is crucial that everyone at the college understands the value of engineering design project-based learning. At Madison College, we encourage our students to invite key stakeholders and VIPs to their final client presentations, so that other faculty, the college president, deans, academic advisors and support staff all get the chance to observe the high quality learning that results from this course. Students are also encouraged to share their success stories with the college media relations and outreach officers. As a result, several past design projects have been featured in the local newspapers and television stations. By sharing their experiences with the larger college community, the students are able to cultivate the critical mass of goodwill that is vital to sustaining a robust engineering design project-based course.

\section{CONCLUSION}

Engineering design projects provide educational experiences for two-year college students that cannot be easily obtained or produced through other means. At Madison College, we have encountered several challenges and learned many lessons in implementing engineering design projects, and we have also marveled at the tremendous benefits that resulted for our students. We hope that some of the findings presented in this paper will be of assistance to other schools, especially community and technical colleges, that are considering the introduction of engineering design projects. Madison College is still developing its approach to engineering design, and we are eager to learn more about the design project experiences of others - including those contained within this special issue of the American Journal of Engineering Education.

\section{ACKNOWLEDGEMENTS}

Several of the engineering projects included in this paper were based upon work supported in part by the National Science Foundation under DUE Grant Awards \# 0501764, 0903293, 1205015, and 1600934. Creation of the Madison College Engineering Design course was made possible by funding from the University of Wisconsin Committee on Baccalaureate Expansion. UW College of Engineering Dean Don Woolston and faculty member John Murphy were invaluable leaders in this collaborative effort between the university and the technical college. UW Professor Marc Anderson shared his decades of experience teaching Engineering Design with the team from Madison College, and referred several clients with unique and challenging design projects. We would like to thank Madison College instructors John Grade, Allen Weishoff, Kris Dressler, and Brian Gilbertson who have team taught this class with us over the past ten years. We also appreciate the support of our Deans, David Shonkwiler and Todd Stebbins, who championed the implementation of the Engineering Design class at Madison College. We have been fortunate to work with many generous and supportive clients, and we appreciate the time and effort that they have taken to partner with the college. Most of all, we thank the numerous students that we have had the pleasure to teach over the past ten years. Their hard work, creativity, innovation and accomplishments are an inspiration to us all.

\section{AUTHOR BIOGRAPHIES}

Ken Walz Earned his B.S. and Ph.D. degrees at the University of Wisconsin. He has taught chemistry, engineering and renewable energy at Madison College since 2003. Walz is an alumnus of the Department of Energy Academies Creating Teacher Scientists program at the National Renewable Energy Laboratory and was recognized as Wisconsin Professor of the Year by the Carnegie Foundation and the Council for Advancement and Support of Education.

Jon Christian Earned his A.A.S. degree in Automotive Technologies and Certificate in Renewable Energy Technology at Madison College He is currently finishing his B.S. in Career and Technical Education at the University of Wisconsin-Stout. Christian has taught metal working classes for students in automotive technology, fabrication, machine tool, welding, and engineering programs at Madison College since 2001. He is also a small business owner and proprietor of a performance automotive fabrication shop. He has designed and fabricated custom parts and engines for hundreds of motorsport racing vehicles, including several championship winning cars. 


\section{REFERENCES}

AACC. (2016). Fast Facts. Washington, DC. American Association of Community Colleges. Retrieved from: http://www.aacc.nche.edu/AboutCC/Documents/AACCFactSheetsR2.pdf

ABET. (2016). Accredited Program Search. Baltimore, MD. ABET. Retrieved from: http://main.abet.org/aps/accreditedprogramsearch.aspx

Atwater, M. (2014). Engineering with your hands: Is shop class back? Engineering. Com. Retrieved from http://www.engineering.com/Education/EducationArticles/ArticleID/7507/Engineering-with-your-hands-Is-shop-classback.aspx

Gillian-Daniel, D. L., \& Walz, K. A. (2016). Teaching-as-research internships: a model for the development of future chemistry faculty and the improvement of teaching in science, technology, engineering, and math. Community College Journal of Research and Practice, 40(2), 133-145.

Hoffman, A., Britton, S., Cadwell, K., \& Walz, K.A. (2011). An integrated approach to introducing biofuels, flash point, and vapor pressure concepts into an introductory college chemistry lab. Journal of Chemical Education 88(2), 197-200.

Hutchins, A. (2015). Why don't future engineers learn real-world skills in school? Macleans. Retrieved from: http://www.macleans.ca/education/university/why-dont-future-engineers-learn-real-world-skills-in-school/

Jackson, C. (2011). The importance of people skills for engineers. Lifecycle Insights. Retrieved from: http://www.lifecycleinsights.com/engineering-profession/people-skills-for-engineers/

Lombardi, M. M. (2007). Authentic learning for the 21st century: An overview. Educause Learning Initiative, 1(2007), 1-12.

Malicky, D. M., Kohl, J. G., \& Huang, M. Z. (2012). Integrating a machine shop class into the mechanical engineering curriculum: experiential and inductive learning. International Journal of Mechanical Engineering Education 38(2).135-46.

Murray. S. (2013). The biggest weakness for engineers is a lack of social skills. Engineering Because. Retrieved from: http://www.engineeringbecause.com/news/engineer-mba/97/biggest-weakness-for-engineers-is-social-skills

NSF. (2010). Characteristics of Recent Science and Engineering Graduates. Arlington, VA. National Science Foundation. Retrieved from http://www.nsf.gov/statistics/recentgrads/

Rule, A. (2006). The components of authentic learning, Journal of Authentic Learning 3(1), 1-10.

Stauth, D. (2002). Engineering students rediscovering shop class. Oregon State University News and Research Communications. Retrieved from: http:/oregonstate.edu/ua/ncs/archives/2002/may/engineering-studentsrediscovering-shop-class

Tspogas, J. (2004). The role of community colleges in the education of recent science and engineering graduates. InfoBrief NSF, 04-315.

US DOL. (2016). Occupational Outlook Handbook. Washington, DC. US Department of Labor, Bureau of Labor Statistics. Retrieved on from: http://www.bls.gov/ooh/occupationfinder.htm?pay=\&education=Associate $\% 26$ rsquo $\% 3 \mathrm{Bs}+$ degree $\&$ training $=\&$ newjobs $=\&$ growth $=\&$ submit $=\mathrm{GO}$

Walz, K.A., Hoffman, A., Britton, S., Cadwell, K., Crain, J., \& Morschauser, P. (2014). biodiesel synthesis, viscosity, and quality control for an introductory chemistry lab. The Chemical Educator 19, 342-346.

Weiner, J. (2014). The STEM Paradoxes: Graduates' lack of non-technical skills. Washington Post. Retrieved from: https://www.washingtonpost.com/blogs/she-the-people/wp/2014/09/26/the-stem-paradox-lack-of-skills-by-stemgraduates-and-not-enough-women/ 


\section{NOTES}

